\title{
ПЕДАГОГІЧНА ТВОРЧІСТЬ: ФІЛОСОФСЬКИЙ, ПСИХОЛОГІЧНИЙ І ПЕДАГОГІЧНИЙ АСПЕКТИ
}

\author{
Мільто Л. О.
}

\section{ВСТУП}

Погляди на педагогічну роботу як творчу діяльність виникли одночасно з розвитком професії педагога, але питання про джерела $\mathrm{i}$ детермінанти творчості, умови творчої самореалізації особистості, взаємозв'язок особистості та творчості, уявлення про закони, що дозволяють описувати творчість, і сьогодні хвилюють учених зі всього світу. Процеси гуманізації та демократизації суспільства, освіти, поява експериментальної педагогіки, інноваційний рух педагогів-новаторів, ідеї вільного виховання завжди посилювали науковий інтерес до педагогічної творчості.

В Україні педагогічна діяльність як творчий процес була i залишається предметом глибоких наукових досліджень, є головною культурологічною, філософської проблемою, що не втрачає своєї актуальності, тому що педагогіка як наука і мистецтво немислима без педагогічної творчості та педагогічної майстерності.

Методологічну основу дослідження педагогічної творчості як наукової проблеми становлять філософські, психологічні, педагогічні, культурологічні, акмеологічні фундаментальні роботи зарубіжних i вітчизняних дослідників, які намагалися створити теорію творчості, з'ясувати, чим є творчий процес, визначити сутнісні ознаки творчого мислення, розкрити механізми творчості.

Варто зауважити, що філософський аспект дослідження проблеми творчості був і залишається предметом досліджень представників різних країн та епох: А. Бергсон, М. Бердяєв, Й. Гете, І. Кант, Ф. Ніцше, О. Спиркин, Й. Фіхте, Ф. Шеллінг, А. Шопенгауер, П. Енгельмеєр та інші вчені, незважаючи на різноманітність наукових підходів до творчості, вважали проблему творчості значимою й актуальною.

Актуальне значення в контексті нашого дослідження мають питання фізіологічних основ, етапів, рівнів, ознак творчості, якостей творчої особистості, механізмів процесу розвитку творчої особистості, які вивчали психологи: Б. Ананьєв, В. Андрєєв, В. Бехтерєв, Д. Богоявленська, Л. Виготський, Н. Кузьміна, О. Лук, В. Моляко, Г. Олпорт, Я. Пономарьов, В. Рибалка, С. Рубінштейн, Е. Фромм та ін. 
Питання, пов'язані 3 проблемами педагогічної творчості, відображені у низці праць Н. Гузій, В. Загв'язинського, І. Зязюна, В. Кан-Калика, Н. Кічук, І. Ісаєва, М. Лазарєва, О. Раченко, С. Сисоєвої, В. Сластьоніна, I. Харламова та ін., котрі розглядають педагогічну діяльність як творчий процес.

\section{1. Методологічні засади педагогічної творчості}

Ще 3 античних часів природа душі та свідомості людини пов'язувалася 3 його здатністю вільно орієнтуватися i діяти в невизначених ситуаціях, які передбачають пошук і знаходження нових способів дії.

У XVIII ст. родоначальник німецької класичної філософії І. Кант створив завершену концепцію творчості. Представники німецької класичної філософії сприйняли ідею створення логіки наукової творчості як науки про творче мислення. У науково-теоретичної діяльності, як зазначав І. Кант, реалізуються всі пізнавальні здібності суб'єкта. Наукова творчість, на думку філософа, становить єдність чуттєвого та раціонального і здійснюється як взаємодія уяви та мислення ${ }^{1}$.

Ідеї I. Канта продовжив розвивати Ф. Шеллінг. Приділяючи особливу увагу інтелектуальній інтуїції, філософ вважав творчість вищою формою людської життєдіяльності. Ф. Шеллінг розумів творчість як безумовну свободу, як необмежену діяльність, у процесі якої вирішуються суперечності, що принципово не розв'язуються старою логікою. Основу свободи філософ бачив у надчуттєвої суті, що пізнається розумом, а також одночасно знаходиться поза всяким причинним зв'язком, тобто у свободі є ніщо інше, як несвідоме 2 .

У філософії кінця ХIX - початку XX ст. творчість стала розглядатися як філософія життя. Одним із головних представників філософського інтуїтивізму і філософії життя був французький філософ А. Бергсон, автор праці «Творча еволюція». На думку автора, вагома роль у творчому процесі належить інтуїції, в основі якої - творчі потенції людини, яку філософ розумів як особливу форми світосприйняття, протиставляючи ii аналітичному, механічному погляду на дійсність.

А. Бергсон вважав, що інтуїція має волю, творчу силу, новизну i допомагає людині від аналітичних i теоретичних суджень, що представляють світ як статичну систему із жорсткими причинно-

\footnotetext{
${ }^{1}$ Кант И. Критика чистого разума. Москва : Мысль, 1994. 591 с.

2 Шеллинг Ф. Ранние философские сочинения. Санкт-Петербург : Алетейя, 2000. 319 c.
} 
наслідковими зв’язками, звернутися до живої та непередбачуваної реальності.

Філософ акцентував увагу на творчості як безперервному процесі народження нового, що становить сутність життя: творчість - це те, що відбувається у природі (у вигляді процесів народження, зростання, дозрівання), у свідомості особистості (у вигляді виникнення нових образів і переживань $)^{3}$.

Отже, у філософії життя творчість розуміється як щось цілісне і неповторне, а інтуїція розглядається як особливий рефлексивний досвід пізнання життя як духовної реальності, що очищує свідомість від всіх понятійних нагромаджень. Зауважимо, що у науковій творчості велике значення інтуїції надавав А. Ейнштейн, котрий вважав інтуїтивні процеси творчим компонентом дослідницької діяльності та зауважував, що логічний апарат, логічні міркування самі по собі не дають можливості створити нове.

Засновник персоналізму, філософ М.Бердяєв, автор творів «Філософія свободи» i «Сенс творчості», писав, що творчість $\epsilon$ обов'язком людини. М. Бердяєв назвав творчих особистостей рушійною силою людства, спрямованого до нового, вищого життя, а творчу діяльність схарактеризував як єдиний вид діяльності, який робить людину людиною, тому що в кожному реальному творчому акті існує елемент свободи, індивідуальності особистості ${ }^{4}$.

На початку XX ст. проблему творчості висвітлив у своїх працях «Теорія творчості», «Питання теорії та психології творчості», «Еврілогія, або загальна теорія творчості» російський філософ, учений i винахідник П. Енгельмеєр, котрий розробив основи нової науки про творчість - «еврілогії». Він писав, що творча особистість $є$ прогресивним елементом, який дає все нове ${ }^{5}$.

Слід підкреслити, що П. Енгельмеєр розвив теорію трьох актів творчості, які складаються 3 трьох етапів: на першому етапі під впливом бажання (творчість зароджується 3 бажання) виникає інтуїтивна ідея, принцип, гіпотеза деякої теорії; на другому етапі формулюється план, схема, проект, здійснюється доказ теорії; на третьому етапі відбувається конструктивна реалізація задуму.

Зауважимо, що третій етап, на думку П. Енгельмеєра, не пов'язаний безпосередньо із творчістю, тому виконання плану може бути доручено відповідному фахівцю. П. Енгельмеєр підкреслював, що геніальність

${ }^{3}$ Бергсон А. Творческая эволюция. Москва : Канон-пресс, 1998. 384 с.

4 Бердяев Н.А. Самопознание. Опыт философской автобиографии. Москва : Книга, 1991. 446 с.

5 Энгельмейер П.К. Теория творчества. Москва : Книжный дом, 2010. 208 с. 
проявляється в першому акті, талант - у другому, старанність, «рутина»- у третьому ${ }^{6}$.

У сучасній філософії творчість розглядається як процес, завдяки якому здійснюється сходження людини до вищих ступенів духовності, моральності та свободи, розвитку особистості й культури. Так, філософ, фахівець у галузі філософських проблем психології й кібернетики О. Спіркін зауважує, що творчість - це властивість свідомості. Вчений звертає увагу на те, що людська думка здатна рухатися не тільки за готовими шаблонами, а й прокладати нові шляхи, ламаючи застарілі норми, здатна до новаторства, творчості ${ }^{7}$.

На думку О. Спіркіна, творча діяльність свідомості тісно пов'язана i3 практичною діяльністю людини, потрібностями людини, що виникають під впливом зовнішнього світу. Саме у творчій діяльності, спрямованій на перетворення світу і підпорядкування його інтересам людини, суспільства, полягає основний життєвий сенс та історична необхідність розвитку свідомості. Вся історія розвитку людства пов'язана з такою діяльністю людей, яка дає нові результати, що мають суспільне значення, що і $є$ творчістю ${ }^{8}$.

Таким чином, вчений дає визначення творчості як духовної діяльності, результатом якої $є$ створення оригінальних цінностей, встановлення нових, раніше невідомих фактів, властивостей i закономірностей матеріального світу і духовної культури.

Проблема творчості завжди привертала увагу психологів. Відомий психолог, психіатр, фізіолог В. Бехтерєв розглядав творчість із позиції рефлексології, називаючи проблемну ситуацію подразником творчості, коли проблема-подразник викликає створення домінанти, навколо якої концентрується необхідний для розв'язання задачі практичний досвід. Учений вважав, що творчість - це відповідна реакція на подразник, а продуктом творчості є сукупність рефлексів ${ }^{9}$.

В. Бехтерєв зауважував, що для будь-якої творчості, окрім навчання, необхідний певний рівень обдарованості. Тим самим учений підкреслював, що психологія творчості нерозривно пов'язана із психологічною проблемою здібностей творчої особистості.

Психолог, філософ, психоаналітик, соціолог, один із засновників неофрейдизму Е. Фромм, праці якого орієнтують людину на пізнання власної індивідуальності, що може бути досягнута тільки через розум, волю, почуття, переживання, збереження ідентичності, свободу,

\footnotetext{
6 Энгельмейер П.К. Теория творчества. Москва : Книжный дом, 2010. 208 с.

${ }^{7}$ Спиркин А.Г. Философия. Москва : Гардарики, 2006. 736 с.

${ }^{8}$ Там само.

${ }^{9}$ Бехтерев В.М. Общие основы рефлексологии человека. Москва - Петроград, 1923. $407 \mathrm{c}$.
} 
творчість, любов, зауважував, що життя індивіда - це процес народження самого себе. Учений називав особистість творцем власного життя, а творчість розглядав як спосіб життя людини. Е. Фромм писав: творчість - це здатність дивуватися і пізнавати, уміння знаходити рішення в нестандартних ситуаціях, націленість на відкриття нового i здатність особистості до глибокого усвідомлення свого власного досвіду $^{10}$.

Науково-технічні досягнення XX ст. дали психологам поштовх до вивчення закономірностей творчого процесу в науці. Так, Г. Альтшуллер - автор посібників «Теорія розв'язання винахідницьких задач» i «Теорія розвитку творчої особистості», який розробляв евристики (алгоритми розв'язання творчих задач), дійшов висновку, що, незважаючи на індивідуальний характер, творчість має певні специфічні закономірності, притаманні лише творчому процесу.

Автор зауважує, що творчість є нормою людського життя, а здатність до творчості - це не талант, а природа людини. Г. Альтшуллер пише, що здібності до творчості є у всіх, але розкрити та розвити творчі здібності можливо лише за бажанням самої особистості у творчості, а також за можливостями іiі реалізації. Головне, на думку вченого, - створення мотивації на творчість та оволодіння технологіями творчої праці. Він підкреслює, що необхідна універсальна освіта, яка не виключає професійної майстерності ${ }^{11}$.

Отже, основним способом розвитку творчої особистості Г. Альтшуллер вважає процес самовдосконалення людини, що свідчить про закономірність реалізації творчих можливостей, саморозвитку та самовираження у процесі творчості.

У сучасній психології творча особистість характеризується наявністю здібностей (загальних, спеціальних), обдарованості, мотивів, знань і умінь, завдяки яким створюється продукт, який відрізняється новизною, оригінальністю.

Так, у працях відомих українських психологів, фахівців у психології творчості (І. Бех, Г. Костюк, В. Моляко, В. Роменець, В. Рибалко та ін.) творча активність розглядається як продуктивний стан особистості, як здатність людини самостійно визначати предмет діяльності та вирішувати, яка саме діяльність буде здійснюватися, щоб реалізувати творчий потенціал. Учені зауважують, що у процесі формування творчої особистості важливішими є внутрішні процеси: уява, фантазія, воля.

${ }^{10}$ Фромм Э. Кризис психоанализа. Москва : АСТ, Полиграфиздат, 2010. 256 с.

11 Альтшуллер Г.С. Найти идею: Введение в ТРИЗ - теорию решения изобретательских задач. Москва : Альпина Паблишер, 2011. 400 с. 
Вагомий внесок у розробку теоретичних засад механізму творчості зроблено академіком Г. Костюком, який досліджував особливості творчого розвитку учнів. Учений підкреслював провідну роль саморуху, спонтанної творчої активності у процесі формуванні та самотворення особистості, розкривав механізми саморозвитку та саморегуляції творчого розвитку ${ }^{12}$.

Науковий інтерес становлять дослідження 3 теорії творчості фундатора української історико-психологічної науки, академіка В. Роменця, який у своїх працях «Фантазія, пізнання, творчість», «Психологія творчості», «Виховання творчих здібностей у студентів» розглядає структуру творчого процесу, формування творчих здібностей людини, розробляє поняттєво-категоріальний апарат творчості. В. Роменець акцентує увагу на тому, що саме завдяки творчості виявляється індивідуальність людини, і трактує творчість як прояснення та душевне очищення, як катарсис ${ }^{13}$.

На значимість творчості як одного із засобів підвищення емоційного тонусу людини звертає увагу В. Рибалко. Він підкреслює, що творчість актуалізує позитивну гаму переживань, яка супроводжує ефективну працю: переживання радощів від зробленого, досягнутого, почуття впевненості у своїх силах, у своєму творчому потенціалі ${ }^{14}$.

Увагу психологів привертає питання про те, які ознаки дозволяють вважати людину творчою особистістю. Так, академік I. Бех вважає, що людська унікальність, індивідуальність тісно пов'язана із проблемою творчості. Учений наголошує, що поняття «творчість» передбачає нове бачення, нове рішення, новий підхід, тобто готовність до відмови від звичних схем i стереотипів поведінки, сприйняття i мислення, готовність змінювати самого себе $\mathrm{e}^{15}$.

Академік В. Моляко, котрий досліджує питання творчої особистості та творчої обдарованості, розглядає творчу людину як таку, що досягла вищого ступеня розвитку, підготовленості до конкретних видів діяльності та життя загалом. Учений зазначає, що рівні творчої діяльності завжди будуть різними, оскільки в кожному конкретному випадку творчі можливості у кожного конкретного фахівця детерміновані його здібностями, обдарованістю, талантом ${ }^{16}$.

12 Костюк Г.С. Навчально-виховний процес і психічний розвиток особистості. Київ : Рад. школа, 1989. 612 с.

${ }^{13}$ Роменець В.А. Психологія творчості. Київ : Либідь, 2001. 288 с.

14 Рибалко В.В. Психологія розвитку творчої особистості. Київ : IЗМН, 1996. $236 \mathrm{c}$.

${ }^{15}$ Бех І.Д. Виховання особистості. Кн. І. Київ : Либідь, 2003. 278 с.

16 Моляко В.О. Актуальні соціально-психологічні аспекти обдарованості. Обдарована дитина. 1998. № 1. С. 4-5. 
Отже, творчість розглядається вченими як діяльність у виробництві істотно нового, як форма пізнання дійсності, як процес формулювання, визначення та вирішення проблем, нестандартних задач. Поняття «творча особистість» пов'язують із творчим потенціалом самої особистості та неодмінною реалізацією творчого потенціалу людини в конкретній діяльності.

Заслуговують на увагу дослідження російського психолога та філософа Д. Богоявленської, котра розробила метод «Креативне поле», який дозволяє адекватно ідентифікувати творчі здібності й обдарованість, більш ефективно реалізовувати розвиток творчих здібностей та індивідуалізацію освіти.

Д. Богоявленська вперше запропонувала розуміння творчості як вихід за межі заданої проблеми, тобто творчість досягається в тому разі, коли суб'єкт може проявити себе на вищому рівні активності. Учена виділяє інтелектуальну активність як одиницю аналізу творчості, а поняття «інтелектуальна активність» трактує в аспекті «ініціативи». Все це достатньо повно відображає сутність цього явища, тому що ініціатива визначає рівень інтелектуальної активності та є ії найбільш специфічним проявом.

Саме Д. Богоявленська ввела до наукового обігу термін «інтелектуальна ініціатива», який визначається як продовження розумової діяльності за межами вже вирішеної проблеми, що не зумовлено ні власними практичними потребами людини, ні зовнішніми негативними оцінками роботи.

Д. Богоявленська розробила класифікацію рівнів інтелектуальної активності: стимульно-продуктивний, евристичний і креативний, які відображають рух думки, іiі послідовне сходження від аналізу одиничного (стимульно-продуктивний рівень), через особливе (евристичний рівень) до загального (креативний рівень).

Перший рівень (стимульно-продуктивний) характеризується таким рівнем інтелектуальної активності людини, за якого добросовісна й енергійна робота залишається в межах знайденого способу дії. Діяльність зумовлена виключно зовнішнім стимулом, для людини характерно безініціативне прийняття того, що задано ззовні.

Другій рівень (евристичний) характеризується пізнавальним інтересом, проявом внутрішньої інтелектуальної ініціативи людини, не стимульованої ні зовнішніми факторами, ні суб'єктивною негативною оцінкою результатів власної діяльності. Методом логічного аналізу людина продовжує розглядати структуру своєї діяльності, порівнювати між собою окремі завдання, що сприяє знаходженню нових, більш ефективних способів розв'язання поставлених задач. Головним інструментом пізнання для таких людей $є$ порівняльний аналіз. 
Третій рівень (креативний) - характеризується тим, що для людини із креативним рівнем інтелектуальної активності емпірично виявлена закономірність стає не просто прийомом розв'язання задачі, а самостійною метою подальшого дослідження, проблемою, заради вивчення якої особистість готова припинити запропоновану ззовні діяльність i почати внутрішньо мотивований пошук найбільш досконалих способів розв'язання задач ${ }^{17}$.

Отже, у своїх дослідженнях Д. Богоявленська розглядає проблему творчості не лише як проблему інтелекту, продуктивного мислення, а i як проблему особистості. Інтелектуальна активність відображає інтелектуально-пізнавальні та мотиваційні характеристики творчої особистості й може використовуватися як критерій оцінки творчого потенціалу особистості.

Питання, пов'язані 3 проблемами педагогічної творчості, відображені у психолого-педагогічних працях (Ю. Азаров, Н. Гузій, В. Загв'язінський, Н. Кічук, М. Лазарєв, М. Нікандров, К. Платонов, I. Раченко, М. Поташник, В. Сластьонін, С. Сисоєва та ін.).

Варто зауважити, що суттєве значення для нашого дослідження мають наукові праці, які розкривають закономірності педагогічної творчості. Одна з перших дослідників педагогічної творчості в Україні С. Сисоєва, котра розглядає педагогічну творчість як об'єктивний творчий процес, виявила такі закономірності педагогічної творчості: зумовленість творчої підготовки вчителя потребами соціальноекономічного і культурного розвитку суспільства; відповідність змісту і форм підготовки вчителя сучасному рівню розвитку психологопедагогічної науки i педагогічної практики; залежність розвитку педагогічної творчості від особистісних якостей вчителя та рівня його творчої педагогічної діяльності ${ }^{18}$.

Відповідно до позиції авторів праці «Педагогічна творчість» В. Кан-Калика, М. Нікандрова педагогічна творчість вчителя включає в себе творчу педагогічну діяльність вчителя i творчу навчальну діяльність учня в їх взаємодії та взаємозв'язку, а також результати їх творчої діяльності, які ведуть до розвитку i саморозвитку як вчителя, так і учнів ${ }^{19}$.

Як відзначає В. Сластьонін, найбільш суттєвими характеристиками творчості є новизна і перетворення. На його думку, ні загальний рівень культури вчителя, ні його ерудиція, ні любов до дітей не можуть бути

17 Богоявленская Д.Б. Психология творческих способностей : монография. Самара : Издательский дом «Федоров», 2009. 416 с.

${ }_{18}^{18}$ Сисоєва С. Основи педагогічної творчості. Київ : Міленіум, 2006. 346 с.

19 Кан-Калик В.А., Никандров Н.Д. Педагогическое творчество. Москва : Педагогика, 1990. 114 с. 
показниками творчо працюючих педагогів. Отже, творчість - це завжди творення чогось нового на основі перетворення пізнаного: нового результату або оригінальних шляхів і методів його отримання ${ }^{20}$.

\section{2. Взаємозв'язок педагогічної творчості та педагогічної майстерності}

На думку багатьох учених (Н. Гузій, В. Загв'язінський, І. Зязюн, 3. Курлянд, М. Лазарев, М. Мажар, В. Міжеріков, О. Мороз, В. Омельяненко, М. Поташник, К. Платонов та ін.), педагогічна творчість тісно повязана з розвитком професійної майстерності та $\epsilon$ обов'язковою умовою педагогічної майстерності вчителя.

Нам імпонує визначення автора праці «Педагогічна творчість учителя» академіка В. Загв'язінського про те, що справжнє виховання i навчання - це завжди творення нового, яке збуджує внутрішні сили людини, тому що творчість є механізмом продуктивного перетворення самої особистості.

За переконанням В. Загв'язінского, без творчості не може бути й педагога-майстра. Саме тому, на думку автора, педагогічна творчість виступає умовою розвитку педагогічної майстерності. Учений зазначає, що, щоб досягати рівня педагогічної майстерності, вчитель зобов'язаний знайти себе, свій стиль педагогічної діяльності, розкрити самобутність своєї натури. Творчий підхід до педагогічної праці, справжня майстерність передбачає індивідуальний стиль діяльності вчителя, в якому реалізуються найбільш сильні сторони його особистості ${ }^{21}$.

Важливими компонентами педагогічної майстерності, що мають творчий характер, В. Загв'язінский вважає самостійну оцінку вчителем педагогічних ситуацій, уміння обгрунтувати ідеї вирішення педагогічних проблем, оптимальний вибір форм, засобів і методів навчання, вміння передбачати та направляти хід подій.

Академік М. Поташник у своєму посібнику для вчителя «Педагогічна творчість: проблеми розвитку і досвід» звертає увагу на те, що вчитель досягає вищого рівня майстерності лише на основі творчості й обов'язково шляхом сумлінності, наполегливості, працездатності, подолання труднощів, перетворюючи уміння в навички, набуваючи педагогічного досвіду ${ }^{22}$.

20 Педагогика : учебное пособие / под ред. В.А. Сластёнина. Москва : Издательский центр «Академия», 2008.

21 Загвязинский В.И. Педагогическое творчество учителя. Москва : Педагогика, 1987. $159 \mathrm{c}$

22 Поташник М.М. Педагогическое творчество: проблемы развития и опыт. Київ : Рад. школа, 1988. 187 с. 
Дослідник проблеми вдосконалення педагогічної майстерності викладачів, білоруський вчений, академік І. Харламов розкрив сутність педагогічної майстерності через педагогічну діяльність учителя. Учений дослідив, що вчитель, який має необхідні професійні якості, навіть покликання до педагогічної діяльності, не завжди володіє педагогічною майстерністю.

Зазначимо, що I. Харламов ще в 90-х pp. XX ст. запропонував чотири стадії професійного розвитку педагога. Перша стадія - педагогічна умілість (досягається у процесі навчання майбутнього вчителя у закладах вищої освіти, а також на початку роботи вчителя у школі); друга стадія педагогічна майстерність (досягається «відшліфовуванням» методів i прийомів застосування психолого-педагогічної теорії на практиці); третя стадія - педагогічна творчість (характеризується самостійною творчою діяльністю в межах реалізації освітньої програми); четверта стадія педагогічне новаторство (досягається через реалізацією педагогом на практиці принципово нових, прогресивних педагогічних ідеї, здатних підвищити якість освіти) ${ }^{23}$.

Розглядаючи педагогічну творчість i майстерність як систему вдосконалення професійно-педагогічної кваліфікації, I. Харламов зауважує, що педагогічна майстерність, творчість і новаторство вчителя повинні бути провідними критеріями професіоналізму.

На нашу думку, педагогічна майстерність визначається через неповторну творчу індивідуальність педагога, яка зумовлює самобутність і унікальність педагогічної праці. Рушійною силою розвитку індивідуальної творчості та майстерності педагога $є$ постійно виникаючі суперечності між типовими діями вчителя і необхідністю знаходити нові варіанти розв'язання педагогічних задач, що виникають у його професійній діяльності.

Звернемо увагу на те, що дослідник педагогічної творчості В. КанКалик причиною проблем, які виникають у професійної діяльності вчителя, вважає те, що сам педагог не завжди враховує й не завжди усвідомлює особливості власної творчої індивідуальності. На думку вченого, пізнати себе, свою індивідуальність у педагогічній діяльності означає зробити засвоєну теорію і досвід інших надбанням власної особистості ${ }^{24}$.

Отже, науковий пошук показав, педагогічна дія вчителя повинна бути адекватна його творчої індивідуальності, тому, орієнтуючись на

23 Харламов И.Ф. О педагогическом мастерстве, творчестве и новаторстве. Педагогика. 1992. № 7-8. С. 11-15.

24 Кан-Калик В.А., Никандров Н.Д. Педагогическое творчество. Москва : Педагогика, 1990. 114 с. 
педагогічний досвід вчителів-новаторів, учитель не повинен механічно копіювати їх методичні прийоми, оскільки творчі педагогічні прийоми i методи одного педагога, механічно реалізовані в системі педагогічної діяльності іншого фахівця, не будуть ефективними.

Проблема індивідуальності, педагогічної творчості, майстерності висвітлювалася й у працях педагога-новатора В. Сухомлинського, котрий зауважував, що сама прекрасне, найтонша методика дієва лише тоді, коли є жива індивідуальність педагога, коли в загальне він вносить щось своє, глибоко продумане.

У період 80-90-х pp. ХХ ст. великого значення набуває розкриття психолого-педагогічного змісту понять «творча особистість», «творча індивідуальність» (О. Абдулліна, Н. Вишнякова, М. Мажар, О. Пехота, К. Платонов, Н. Посталюк та ін.).

Досліджуючи розвиток творчої індивідуальності вчителя як необхідної складової частини педагогічної майстерності, М. Мажар визначив соціальні та психолого-педагогічні умови розвитку творчої індивідуальності вчителя.

Серед необхідних умов дослідник виокремив діалектичну єдність розвитку та саморозвитку творчої індивідуальності вчителя, орієнтацію процесу формування особистості вчителя на потенційні індивідуальні особливості людини як суб'єкта майбутньої професійної діяльності та на рівень вимог, що висуваються до людини з боку педагогічної професії.

Обов'язковою умовою розвитку творчої індивідуальності, на думку М. Мажара, є наявність творчого потенціалу людини, що визначає іiі професійну придатність до педагогічної діяльності та можливість суб'єктного розвитку, а також включення науково-практичної діагностики професійно-педагогічної придатності до процесу формування особистості майбутнього вчителя і розвитку його творчої індивідуальності. Дослідник довів, що важливою умовою розвитку творчої індивідуальності $\epsilon$ реалізація гуманістичної парадигми професійної підготовки майбутнього вчителя, яка передбачає особистісно і практико-орієнтовані педагогічні технології розвитку та саморозвитку його особистості ${ }^{25}$.

У наукових працях українських дослідників О. Мороза та В. Омельяненко також простежується взаємозв'язок педагогічної творчості та майстерності. Учені розглядають педагогічну майстерність як досконале, творче виконання педагогом професійних функцій на рівні мистецтва, результатом чого є створення оптимальних соціальнопсихологічних умов для становлення особистості кожного вихованця,

\footnotetext{
${ }^{25}$ Мажар Н.Е. Теоретические основы развития творческой индивидуальности : дис. ... докт. пед. наук. Москва, 1996. 348 с.
} 
забезпечення високого рівня інтелектуального розвитку, виховання кращих моральних якостей, духовного збагачення учасників навчально-виховного процесу ${ }^{26}$.

Звертаючи увагу на взаємозв'язок між педагогічною творчістю і рівнем розвитку педагогічної майстерності, В. Паламарчук тлумачить педагогічну майстерність як складне i багатогранне явище, що $\epsilon$ сплавом професійно значущих якостей учителя, професійнопедагогічних знань, умінь і досвіду творчої діяльності, що призводить до професійного успіху ${ }^{27}$.

Значний професійний інтерес представляють погляди В. Сластьоніна на педагогічну майстерність, який показником педагогічної майстерності визначив здатність вчителя володіти спеціальними педагогічними вміннями на інтуїтивному, репродуктивному та творчому рівнях. Одним із головних показників педагогічної майстерності вчений вважав рівень сформованості творчої індивідуальності фахівця.

У наукових дослідженнях В. Сластьоніна категорія «творча індивідуальність» трактується як базова для педагогіки та психології, оскільки творчий характер педагогічної діяльності об'єктивно передбачає наявність творчої індивідуальності вчителя. Залежно від розвитку педагогічної майстерності В. Сластьонін розподілив учителів на п'ять груп. До першої групи ввійшли вчителі, які вже на початку своєї професійної діяльності досягли достатньо високого рівня педагогічної майстерності, що пояснюється їх моральною та психологічною готовністю до педагогічної праці, розумінням соціальної значущості вчительської професії, постійним прагненням до самовдосконалення.

Другу групу становлять учителі, у яких розвиток педагогічної майстерності превалює в навчальній діяльності. Учителі, котрі представляють третю групу, мають слабку загальнопедагогічну підготовку, тому проходять довгий період розвитку майстерності. До четвертої групи входять учителі, які механічно копіюють чужий досвід, що дозволяе їм досягти певного рівня майстерності, проте відсутність творчості не дає можливості виробити власний професійний почерк. До п’ятої групи належать учителі, що не досягли справжньої майстерності, оскільки не відчули задоволення від обраної професії ${ }^{28}$.

Важливе значення для дослідження проблеми педагогічної творчості та педагогічної майстерності мають праці українського

\footnotetext{
${ }^{26}$ Мороз О.Г., Омеляненко В.П. Перші кроки до майстерності. Київ : Товариство «Знання». 1992. $112 \mathrm{c.}$

27 Паламарчук В.Ф. Як виростити інтелектуала: посібник для вчителів і керівників шкіл. Тернопіль : Навчальна книга - Богдан, 2000. 152 с.

28 Педагогика : учебное пособие / под ред. В.А. Сластёнина. Москва : Издательский центр «Академия», 2008.
} 
філософа, психолога, педагога, фундатора педагогічної майстерності, академіка I. Зязюна, який наголошував, що майстерність педагога стверджується через творчість і втілюється в ній. На думку вченого, зовнішньо педагогічна майстерність виявляється в успішному вирішенні різноманітних задач навчання, конкретні показники майстерності виявляються у високому рівні виконавства, якості праці, доцільних, адекватних педагогічним ситуаціям діях викладача, досягненні високих результатів навчання і виховання.

Слушним є визначення I. Зязюна, що майстерність - це особливий стан, який дає певний рівень професійної свободи вчителю, педагогу, вихователю, керівникові навчального закладу, визначаючи межі можливого і внутрішньо дозволеного в педагогічній реальності ${ }^{29}$.

Відповідно до позиції І. Зязюна педагогічна майстерність вчителя $€$ стійкою системою теоретично обгрунтованих і практично виправданих педагогічних дій і операцій, які забезпечують високий рівень інформаційної взаємодії між викладачем і його учнями. Сутність же майстерності полягає в особистості вчителя, його позиції, здатності проявляти творчу ініціативу на грунті реалізації власної системи цінностей.

Учений писав, що педагогічний досвід - це досвід творчий, переломлений крізь індивідуальність учителя, сліпе копіювання вчителем чужого досвіду не забезпечує формування власного педагогічного досвіду. На думку вченого, та частина педагогічного досвіду, яка піддається відтворенню, повинна чітко окреслитися, технологічно виокремитися у вигляді прийомів, операцій, процедур. Тільки після таких педагогічних технологій передовий досвід одного педагога може стати надбанням іншого. За визначенням I. Зязюна, педагогічна технологія повинна бути творчо переосмисленою, тому що технологія відтворюється в режимі взаємодії конкретного вчителя і конкретного учня. Він зауважував, що одна й та сама технологія може бути захоплююче чарівною, ефективною $\mathrm{i}$ може бути реалізована убого, потворно, та зазначав, що будь-яка педагогічна технологія та майстерність як технологічний процес не виключає і не обмежує творчості, тому що іiі розробка і застосування вимагає найвищої творчої активності вчителя.

\section{ВИСНОВКИ}

Отже, ретроспективний аналіз проблеми творчості у філософському, психологічному та педагогічному аспектах засвідчив, що джерелом педагогічної творчості $\epsilon$ світовий культурний досвід філософів, психологів, педагогів-новаторів, який базується на ідеалах

29 Зязюн І.А. Філософія педагогічної дії : монографія. Черкаси : Вид. від. ЧНУ ім. Богдана Хмельницького, 2008. 608 с. 
гуманізму, пошуку істини, прагнень і можливостей для самовизначення та кращої реалізації свого творчого потенціалу.

У філософському аспекті творчість розглядається як діяльність людини, що породжує якісно нове в інтересах соціального прогресу, творчість сприймається як форма активності людини, яка виражається у різноманітних видах діяльності й веде до свободи, гуманізації суспільних відносин і забезпечує розвиток та самореалізацію особистості, змінює самого суб'єкта творчості. У психологічних дослідженнях творчість розглядається як вища форма діяльності особистості, що вимагає від людини тривалої підготовки, ерудиції, наполегливої праці. Психологи досліджують роль особистості в творчому процесі, розкривають сутнісні механізми творчості, умови розвитку творчих здібностей.

Визначено, що на педагогічному рівні детально розглядаються процеси формування і реалізації творчості у професійній діяльності вчителя. Синтезуючи різноманітні наукові підходи до творчості, визначено, що поняття «педагогічна творчість» грунтується на визначенні такого феномену, як творчість. Провідними характеристиками педагогічної творчості виступають новизна, оригінальність, нестандартність, інноваційність процесу та результату педагогічної діяльності, вихід за межі відомого в педагогічній науці та практиці. 3'ясовано, що елементи новизни у педагогічної творчості вчителя найчастіше пов'язані не з продукуванням нових прийомів навчання, а з їх модернізацією.

3'ясовано, що сучасні дослідники педагогічної творчості приділяють увагу таким основним проблемам, як індивідуальний стиль діяльності особистості педагога, творчої індивідуальності вчителя, яка вважається вищою характеристикою педагогічної творчості та включає особистісні якості особистості: творчу ініціативу, пізнавальні здібності та кругозір, почуття новизни, чуйність до суперечностей і готовність до розв'язання проблем.

Доведено, що педагогічна творчість тісно пов'язана 3 педагогічною майстерністю і є обов'язковою умовою професійного розвитку вчителя. У сучасних психолого-педагогічних дослідженнях педагогічну майстерність учителя розглядають у контексті вивчення педагогічного досвіду, педагогічної творчості, самовдосконалення. Аналіз різноманітних наукових підходів у дослідженні педагогічної майстерності засвідчив, що це поняття розглядається як вияв найвищої форми активності особистості вчителя, що базується на гуманізмі та реалізується в доцільному використанні методів і засобів педагогічної взаємодії в конкретної педагогічної ситуації.

Отже, педагогічна майстерність учителя, своєрідна й унікальна, тому що, незважаючи на свій технологічний характер, тісно пов'язана 3 
педагогічною творчістю і $є$ неповторним процесом педагогічної дії вчителя. Педагогічна майстерність, як і педагогічна творчість має індивідуальний стиль фахівця і не зводиться до окремих знань і умінь вчителя, а $є$ продуктом синтезу теоретичних знань і основою практичних дій та професійного досвіду особистості, формуються в контексті індивідуальності вчителя. Педагогічна творчість і педагогічна майстерність - два взаємозумовлені процеси неперервної самоосвіти, постійного професійного самовдосконалення вчителя, розвитку його особистих якостей, необхідних для ефективного розв'язання педагогічних задач.

\section{АНОТАЦІЯ}

У статті здійснено ретроспективний аналіз філософського, психологічного та педагогічного аспектів визначення поняття «творчість», «педагогічна творчість», «творча особистість». З'ясовано, що педагогічна творчість містить елементи новизни, що найчастіше пов'язано не стільки із продукуванням прийомів навчально-виховної діяльності, скільки з деякою ї модернізацією. У науковому обігу поняття педагогічної творчості розглядається як творчий процес у діяльності педагога, як інтегративна якість його особистості та як критерій якісного професійного становлення вчителя. Розглянуте співвідношення понять «педагогічна творчість» i «педагогічна майстерність». Визначено, що педагогічна творчість тісно повязана 3 педагогічною майстерностю вчителя та $\epsilon$ обов'язковою умовою iii розвитку.

\section{ЛIТЕРАТУРА}

1. Альтшуллер Г.С. Найти идею: Введение в ТРИЗ - теорию решения изобретательских задач. Москва : Альпина Паблишер, 2011. 400 с.

2. Бергсон А. Творческая эволюция. Москва : Канон-пресс, 1998. 384 c.

3. Бердяев Н.А. Самопознание. Опыт философской автобиографии. Москва : Книга, 1991. 446 с.

4. Бехтерев В.М. Общие основы рефлексологии человека. Москва Петроград, 1923. 407 с.

5. Богоявленская Д.Б. Психология творческих способностей : монография. Самара : Издательский дом «Федоров», 2009. 416 с.

6. Бех І.Д. Виховання особистості. Кн. І. Київ : Либідь, 2003. 278 с.

7. Загвязинский В.И. Педагогическое творчество учителя. Москва : Педагогика, 1987. $159 \mathrm{c}$.

8. Зязюн І.А. Філософія педагогічної дії : монографія. Черкаси : Вид. від. ЧНУ ім. Богдана Хмельницького, 2008. 608 с.

9. Кан-Калик В.А., Никандров Н.Д. Педагогическое творчество. Москва : Педагогика, 1990.114 с.

10. Кант И. Критика чистого разума. Москва : Мысль, 1994. 591 с. 
11. Костюк Г.С. Навчально-виховний процес і психічний розвиток особистості. Київ : Рад. школа, 1989. 612 с.

12. Мороз О.., Омеляненко В.П. Перші кроки до майстерності. Київ : Товариство «Знання». 1992. 112 с.

13. Мажар Н.Е. Теоретические основы развития творческой индивидуальности : дис. ... докт. пед. наук. Москва, 1996. 348 с.

14. Моляко В.О. Актуальні соціально-психологічні аспекти обдарованості. Обдарована дитина. 1998. № 1. С. 4-5.

15. Паламарчук В.Ф. Як виростити інтелектуала : посібник для вчителів і керівників шкіл. Тернопіль : Навчальна книга - Богдан, 2000. 152 с.

16. Педагогічна майстерність : підручник / за ред. I.А. Зязюна). Київ : Богданова А.М., 2008. 376 с.

17. Педагогічна творчість: методологія, теорія, технології / за заг. ред. С. Сисоєвої, Н. Гузій. Київ : НПУ імені М. П. Драгоманова, 2005. 183 с.

18. Педагогика : учебное пособие / под ред. В.А. Сластёнина. Москва : Издательский центр «Академия», 2008.

19. Поташник M.M. Педагогическое творчество: проблемы развития и опыт. Київ : Рад. школа, 1988. 187 с.

20. Рибалко В.В. Психологія розвитку творчої особистості. Київ : I3MH, 1996. $236 \mathrm{c}$.

21. Роменець В.А. Психологія творчості. Київ : Либідь, 2001. 288 с.

22. Сухомлинский В.А. Сердце отдаю детям. Київ : Радянська школа, 1981. $382 \mathrm{c.}$

23. Спиркин А.Г. Философия. Москва : Гардарики, 2006. 736 с.

24. Сисоєва С. Основи педагогічної творчості. Київ : Міленіум, 2006. $346 \mathrm{c}$.

25. Фромм Э. Кризис психоанализа. Москва : АСТ, Полиграфиздат, 2010. $256 \mathrm{c}$.

26. Харламов И.Ф. О педагогическом мастерстве, творчестве и новаторстве. Педагогика. 1992. № 7-8. С. 11-15.

27. Шеллинг Ф. Ранние философские сочинения. СанктПетербург : Алетейя, 2000. 319 с.

28. Энгельмейер П.К. Теория творчества. Москва : Книжный дом, 2010. 208 c.

\section{Information about the author: \\ Milto l. O.,}

Doctor of Pedagogical Sciences, Professor,

Herd of the Department of Pedagogy and Psychology of Higher Education

National Pedagogical Dragomanov University 9, Pyrohov str., Kyiv, Ukraine 